Katarzyna Walicka-Serzysko ${ }^{1,2}$, Teresa Orlik ${ }^{3}$, Dorota Sands ${ }^{1,2}$, Natalia Jeneralska ${ }^{2}$, Anna Popiel ${ }^{4}$, Wojciech Skorupa ${ }^{5}$, Andrzej Pogorzelski ${ }^{6}$, Szczepan Cofta ${ }^{7}$

${ }^{1}$ Cystic Fibrosis Department, Institute of Mother and Child, Warsaw, Poland;

${ }^{2}$ Cystic Fibrosis Centre, Pediatric Hospital in Dziekanów Leśny, Łomianki, Poland

${ }^{3}$ Rehabilitation Department, Institute of Mother and Child, Warsaw, Poland

${ }^{4}$ Department of Pneumology, Pediatric Allergology and Clinical Immunology of the K. Marcinkowski Medical University, Poznań, Poland ${ }^{5}$ Institute of Tuberculosis and Lung Diseases, Warsaw, Poland

${ }^{6}$ Department of Pneumonology and Cystic Fibrosis, Institute of Tuberculosis and Lung Diseases, Regional Department, Rabka-Zdrój, Poland

${ }^{7}$ University Hospital of Lord's Transfiguration, Partner of Poznań University of Medical Science, Poznań, Poland

\title{
Nebulisation therapy in patients with cystic fibrosis - consensus of the Polish Cystic Fibrosis Society
}

\begin{abstract}
Introduction: Nebulisation therapy plays a key role in the treatment of cystic fibrosis (CF). Its effectiveness depends on obtaining a high concentration of drugs in the respiratory tract. Particle deposition is determined by many factors resulting, inter alia, from the essence of the lung disease (mucus, structural changes such as bronchiectasis, fibrous changes, cirrhosis) and the quality of the aerosol and breathing techniques during the procedure.

Aims: A large variety of available drugs that can be used in the form of aerosols (bronchodilators, mucolytics, antibiotics), a wide range of devices for their delivery, and a different approach to the practical aspect related to the use of inhalation, makes it necessary to systematize knowledge in order to optimize nebulisation therapy. The paper presents an overview of inhaled drugs used in cystic fibrosis and their administration devices.

Results: The principles of inhalation antibiotic therapy, which constitute the basis for the treatment of primary and chronic respiratory tract infections of Pseudomonas aeruginosa etiology, are discussed in detail. A very important issue was raised related to the proper selection of devices and their proper operation. In the context of the key role of nebulisation therapy in cystic fibrosis, a huge problem is the limited availability of inhaled antibiotics in Poland.

Conclusions: The possibility of choosing an antibiotic and using alternating therapy increases the effectiveness of inhalation treatment, which results in slowing down the progress of bronchopulmonary disease and extending the life of patients.
\end{abstract}

Key words: cystic fibrosis, chest physiotherapy, nebulisers system, drug deposition, aerosol

Adv Respir Med. 2021; 89: 570-580

\section{Introduction}

Progress in medicine at the turn of the last four decades has led to a significant improvement in the treatment and care of patients with cystic fibrosis $[1,2]$. The quality and length of life is determined by the course of bronchopulmonary disease, and respiratory failure is the most common cause of death. The basic genetic defect underlying the pathogenesis of cystic fibrosis leads to impaired mucociliary clearance of the airways, formation of mucus plugs, and secondary infections with pathogens such as Staphylococcus aureus and Pseudomonas aeruginosa and others. Chronic infection accompanied by neutrophilic inflammation, recurrent exacerbations of bronchopulmonary disease, cause gradual impairment of lung function and progression of permanent changes such as bronchiectasis, cirrhoidal and fibrous lesions. Chronic treatment of lung disease and treatment of exacerbations are the basic measures to slow

Address for correspondence: Katarzyna Walicka-Serzysko, Cystic Fibrosis Department, Institute of Mother and Child, Kasprzaka 17A, 01-211 Warsaw, Poland; Cystic Fibrosis Centre, Pediatric Hospital in Dziekanów Leśny, M. Konopnickiej 65, 05-092 Łomianki, Poland, e-mail: katarzyna.walicka@imid.med.pl

DOI: 10.5603/ARM.a2021.0107 | Received: 2021.11.08 | Copyright (C) 2021 PTChP | ISSN 2451-4934 | e-ISSN 2543-6031

This article is available in open access under Creative Common Attribution-Non-Commercial-No Derivatives 4.0 International (CC BY-NC-ND 4.0) license, allowing to download articles and share them with others as long as they credit the authors and the publisher, but without permission to change them in any way or use them commercially. 
Table 1. Mechanisms of drug deposition in the respiratory tract

\begin{tabular}{|c|c|c|c|c|}
\hline $\begin{array}{l}\text { Type of } \\
\text { deposition }\end{array}$ & $\begin{array}{c}\text { Mass median } \\
\text { diameter }\end{array}$ & Mechanism description & Respiratory tract & Remarks \\
\hline Inertia & $>5 \mu \mathrm{m}$ & $\begin{array}{l}\text { Depends on the inspiratory flow } \\
\text { velocity through the airways. } \\
\text { Settlement of particles occurs } \\
\text { as a result of their collision } \\
\text { with the airway wall }\end{array}$ & $\begin{array}{l}\text { Main deposition } \\
\text { mechanism in the upper } \\
\text { respiratory tract }\end{array}$ & $\begin{array}{c}\text { With a high inspiratory flow, } \\
\text { the likelihood of particles smaller } \\
\text { than } 5 \mu \text { m being deposited } \\
\text { in the upper respiratory tract } \\
\text { increases }\end{array}$ \\
\hline Sedimentation & $1-5 \mu \mathrm{m}$ & $\begin{array}{l}\text { Under the influence of gravity, } \\
\text { the particles settle, the number } \\
\text { of which is directly proportional } \\
\text { to the time the air is held } \\
\text { at the top of the inhalation }\end{array}$ & $\begin{array}{c}\text { Lobar and segment } \\
\text { bronchi }\end{array}$ & $\begin{array}{l}\text { A few seconds' breath hold } \\
\text { at the apex of inspiration allows } \\
\text { more particles to be deposited } \\
\text { in segmental bronchi }\end{array}$ \\
\hline Diffusion & $<1 \mu \mathrm{m}$ & $\begin{array}{l}\text { Particle deposition due } \\
\text { to Brownian motion }\end{array}$ & Peripheral airway & $\begin{array}{l}\text { Increase in inspiratory volume } \\
\text { with reduced inspiratory flow } \\
\text { significantly increases drug } \\
\text { deposition in peripheral bronchi }\end{array}$ \\
\hline
\end{tabular}

down the progression of the disease. In this context, bronchial tree physiotherapy including inhalation therapy, bronchial drainage and education of the patient and family are the main elements of both European [2, 3] and American [4] guidelines. Comprehensive physiotherapy should be implemented in the treatment of every patient with cystic fibrosis from the moment of diagnosis and modified at every stage of life, taking into account age, clinical condition and the possibility of cooperation.

\section{Drug deposition in the lungs and the effectiveness of nebulisation therapy}

The effectiveness of nebulisation therapy, both in the central and peripheral airways, is influenced by many factors. The most important of them are:

- related to the laws of physics,

- related to the quality of the aerosol,

- patient-dependent $[5,6]$.

\section{Factors influencing drug deposition related to the laws of physics}

Drug deposition depends on 3 main mechanisms:

- inertia - this is the body's ability to maintain its state of motion due to the force of inertia; a mechanism typical of particles with a diameter greater than $5 \mu \mathrm{m}$ and their deposition in the upper respiratory tract;

- sedimentation - this is the falling of particles due to gravity; concerns particles 1-5 $\mu \mathrm{m}$ in diameter and their settlement in the bronchial tree;
- diffusion, typical for particles $<1 \mu \mathrm{m}$ in diameter, deposited under the influence of Brownian motion (Table 1, Figure 1).

\section{Factors influencing drug deposition related to aerosol quality}

The most important factors in determining the quality of an aerosol are drug particle shape, size, density, as well as electric charge and hygroscopicity. Usually, the following parameters are taken into account:

- mass median diameter - MMD;

- median aerodynamic diameter of particles MAD;

- mass median aerodynamic diameter MMAD, describing the particle size distribution in the aerosol; its value means that $50 \%$ of the aerosol particles will have a smaller or equal diameter than the specified value. It is a more accurate indicator of aerosol quality than MAD;

- fine particle fraction of the aerosol - FPF, describing the particle size distribution; it determines the percentage of particles $\leq 5 \mu \mathrm{m}$ in diameter in the aerosol as a measure of the spread of the drug in the lower respiratory tract.

\section{Patient-dependent determinants of drug deposition and distribution include}

- the diameter of the central airways (small children have a narrower airways and higher inspiratory flow compared to adults, resulting in deposition mainly in the central and lobar bronchi). In this context, it is extremely important to correctly select a nebuliser for the 


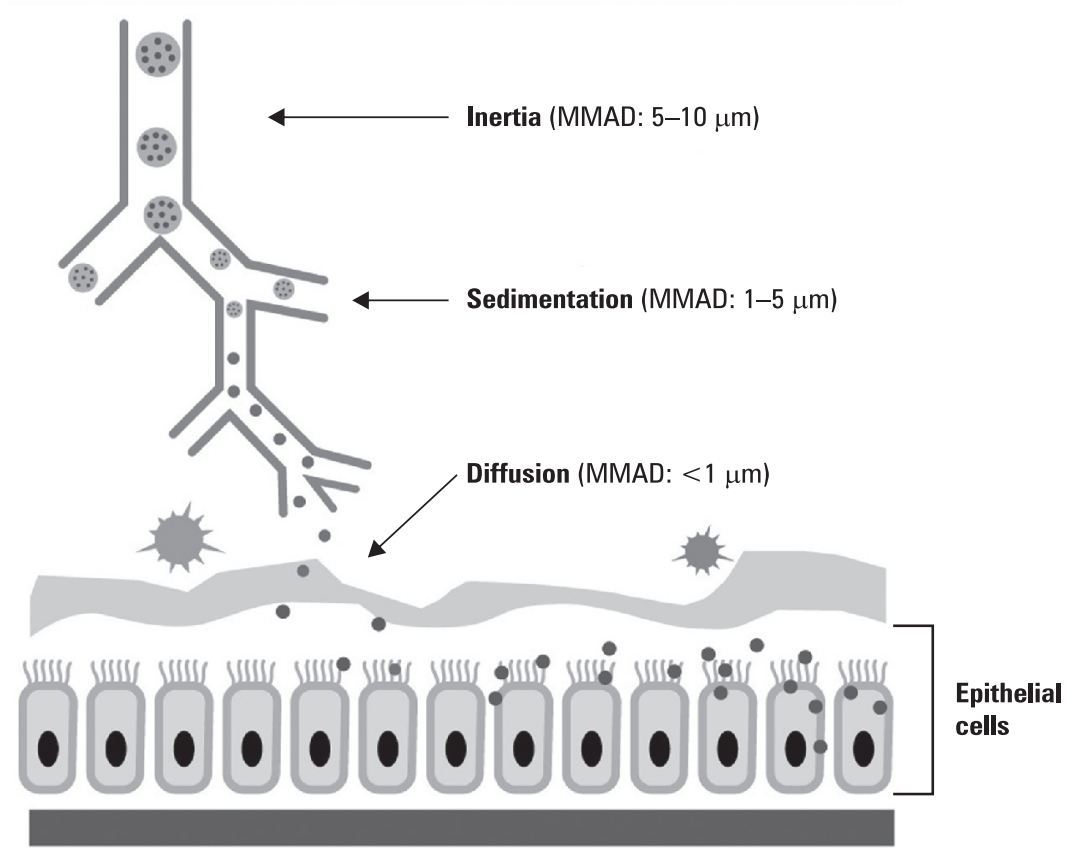

Figure 1. Mechanisms of the deposition of aerosol particles in individual parts of the respiratory tract

MMAD — (mass median aerodynamic diameter) median of the mass distribution of aerosol particles in relation to the aerodynamic diameter [5]

youngest children, which will produce the highest-class aerosol with the lowest MMD/ MMAD values;

- breathing pattern, which depends on age and physical fitness and the severity of the disease. The ability to perform specific breathing techniques dependent on cooperation with the patient plays an important role; high inspiratory flow creates more turbulence in the central airways, which leads to more drug depositing in the central bronchi; in turn, reducing the inspiratory flow while increasing the inspiratory volume will result in less turbulence and increase the likelihood of molecules reaching the peripheral airways. Guidelines for breathing maneuvers are different depending on the device.

During nebulisation, it is recommended that the patient takes slow, deep breaths during inhalation with a pause of 3 seconds at the peak of the inspiration, so that a large number of the smallest particles have a chance of reaching the peripheral airways.

- the presence of structural abnormalities of the airways and/or mucus, disturbing the airflow, reduces drug deposition at sites of airway obstruction;

- homogeneity of lung ventilation, that is, the ability of the lungs to expand evenly. Good drug deposition depends on proper lung ventilation. Structural abnormalities of the lungs disturbing ventilation, e.g. fibrous changes in patients with cystic fibrosis have a negative effect on drug distribution. As a result, there is a preferential airflow to healthier regions of the lung and deposition of drug particles mainly there (Figure 2).

\section{Devices for inhalation}

Inhalation devices used by patients with cystic fibrosis can be divided into 3 categories:

1. Nebuliser Systems:

a. pneumatic, compatible with Jet nebulisers,

b. ultrasonic,

c. mesh (MESH type) - vibrating membrane;

2. pressurized meter-dose inhalers (pMDI), including breath-activated pMDI (BA-pMDI) or in combination with a valved holding chamber (VHC);

3. dry powder inhalers (DPI).

\section{Nebuliser Systems}

Pneumatic nebulisers

The force that breaks down a liquid medicine into very fine particles is compressed air. The 


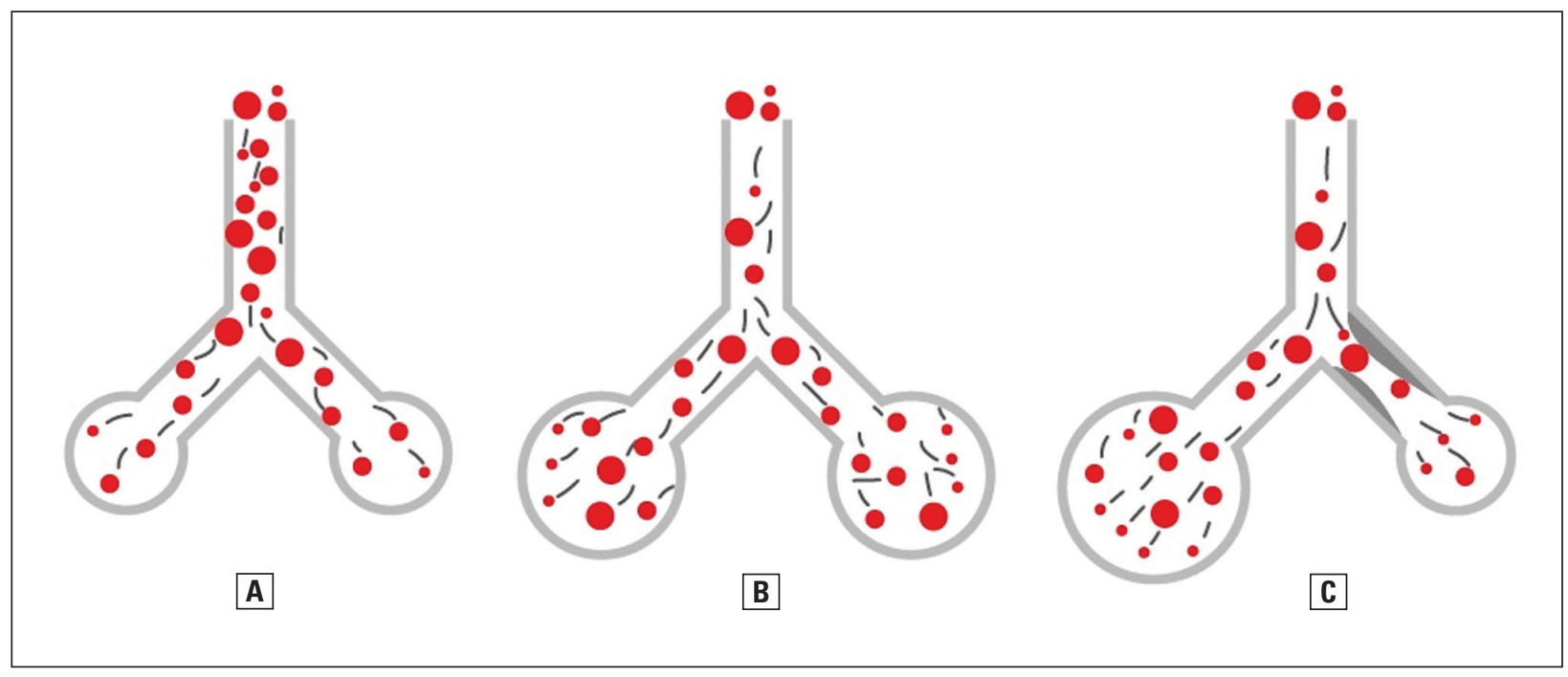

Figure 2. Scheme of deposition of aerosol particles of different sizes $(1,3$ and $5 \mu \mathrm{m})$ in the bronchial tree of a healthy person $(A, B)$ and a patient with lung disease (C). A. Homogeneous distribution of the drug in the lung segments of a healthy person while breathing calmly. Deposition is greater in the central airways compared to the peripheral airways and lung parenchyma; $B$. The same person takes a deep breath, more of the drug reaches the peripheral airways and the flesh, the drug is evenly distributed in both lobes; C. Lung of a patient with lung disease and single-lobe lesions: during a quick and deep inhalation in the affected lobe, there is increased airway resistance and decreased compliance compared to the healthy part of the lung. As a result, there is a preferential airflow to a healthier airfoil; ultimately, the healthier lobe receives more drug than the diseased lobe [6]

quality of the aerosol is determined by the air pressure expanding at the outlet of the nebuliser nozzle (0.7-2 bar), called the operating pressure. Higher pressure will break the drug into large, irregular particles, less pressure than 0.7 bar will not break the drug down. The operating pressure depends on the pressure created by the compressor and the diameter of the nozzle outlet passage in the nebuliser.

\section{Ultrasonic nebulisers}

Ultrasound is the force that breaks down liquid medicine into particles. The oscillator's vibration frequency is $1-2 \mathrm{MHz}$. The particles produced in ultrasonic devices vary in size and shape.

\section{MESH or vibrating membrane nebulisers}

The best drug deposition in the peripheral bronchus is achieved with particles with an ideal sphere shape. MESH nebuliser systems have a perforated membrane (mesh) through which drug particles pass, obtaining a perfect ball shape. The force breaking down the drug is ultrasound with a vibration frequency of approximately $117 \mathrm{kHz}$. MESH nebuliser systems allow you to shorten the inhalation time while obtaining the appropriate drug concentration in the lungs.

Characteristics of a proper nebuliser system

- good quality of the aerosol,

- low residual capacity,
- high efficiency (volume/time),

- allows the use of a variable inspiratory volume,

- good quality and shape of the mouthpiece,

- can be used in positions other than sitting. It applies to patients with inadequate ventilation of the lungs, for which the so-called positioning to use gravity should be applied to obtain better drug deposition in diseased areas,

- comfortable to hold in the hand,

- noise volume $<60 \mathrm{~dB}$.

\section{Nebuliser efficiency and aerosol quality}

The efficiency of a nebuliser is determined by the amount of drug sprayed per unit time, most often given in $\mathrm{mL} / \mathrm{min}$ or $\mathrm{mg} / \mathrm{min}$. The high efficiency of the nebuliser often means a shorter inhalation time but a poorer aerosol quality (MMD/MMAD > $5 \mu \mathrm{m}$ ). This dependence raises a lot of controversy due to the apparent contradiction in assessing the quality of the nebuliser system. There are different priorities, different for clinicians and patients. Clinicians want a very good quality aerosol (MMD/MMAD $<3 \mu \mathrm{m}$ ), which is a condition for obtaining a high concentration of the drug in the lungs. In turn, patients and their caregivers care about the shortest possible inhalation time. Work has been underway for many years to reconcile these two factors. MESH nebuliser systems, thanks to the dense aerosol 
Table 2. Characteristics of nebulisers used in patients with cystic fibrosis - based on [7-11]. Aerosol parameters were determined based on: ${ }^{1}$ the mass median diameter (MMD) or ${ }^{2}$ the mass median aerodynamic diameter (MMAD)

\begin{tabular}{|c|c|c|c|}
\hline Nebuliser & Total output rate & $\begin{array}{l}\text { Aerosol parameters } \\
\text { MMD }^{1} / M_{M} \text { MD }^{2}\end{array}$ & $\begin{array}{l}\text { Percentage share of particles } \\
\text { smaller than } 5 \mu \mathrm{m}\end{array}$ \\
\hline $\begin{array}{l}\text { PARI LC SPRINT BABY* } \\
\text { (red insert) }\end{array}$ & $150 \mathrm{mg} / \mathrm{min}$ & $2.5 \mu \mathrm{m}^{1}$ & $82 \%$ \\
\hline $\begin{array}{l}\text { PARI LC SPRINT STAR** } \\
\text { (red insert) }\end{array}$ & $296 \mathrm{mg} / \mathrm{min}$ & $2.2 \mu \mathrm{m}^{1}$ & $86 \%$ \\
\hline $\begin{array}{l}\text { PARI LC SPRINT Junior** } \\
\text { (yellow insert) }\end{array}$ & $370 \mathrm{mg} / \mathrm{min}$ & $2.9 \mu \mathrm{m}^{1}$ & $76 \%$ \\
\hline $\begin{array}{l}\text { PARI LC SPRINT*** } \\
\text { (blue insert) }\end{array}$ & $600 \mathrm{mg} / \mathrm{min}$ & $3.5 \mu \mathrm{m}^{1}$ & $67 \%$ \\
\hline $\begin{array}{l}\text { PARI LC SPRINT STAR }{ }^{* * *} \\
\text { (red insert) }\end{array}$ & $450 \mathrm{mg} / \mathrm{min}$ & $2.2 \mu \mathrm{m}^{1}$ & $89 \%$ \\
\hline PARI LC PLUS ${ }^{* * *}$ & $440 \mathrm{mg} / \mathrm{min}$ & $3.6 \mu \mathrm{m}^{1}$ & $67 \%$ \\
\hline AeroEclipse XL BAN & no data & $\begin{array}{l}4.3 \mu \mathrm{m} \text { at } 3.5 \mathrm{~L} / \mathrm{min}^{2} \\
3.7 \mu \mathrm{m} \text { at } 5.0 \mathrm{~L} / \mathrm{min}^{2}\end{array}$ & $\begin{array}{l}58 \% \text { at } 3.5 \mathrm{~L} / \mathrm{min} \\
67 \% \text { at } 5.0 \mathrm{~L} / \mathrm{min}\end{array}$ \\
\hline SideStream & $300 \mathrm{mg} / \mathrm{min}$ & $3.17 \mu \mathrm{m}^{2}$ & $77 \%$ \\
\hline eFlow Rapid & $610 \mathrm{mg} / \mathrm{min}$ & $4.1 \mu \mathrm{m}^{1}$ & $69 \%$ \\
\hline InnoSpire Go & $0.26 \mathrm{~mL} / \mathrm{min}$ & $3.99 \mu \mathrm{m}^{2}$ & $52.3 \%$ \\
\hline
\end{tabular}

PARI LC SPRINT/LC PLUS: Measured with $0.9 \%$ NaCl in Malvern Master Sizer, $23{ }^{\circ} \mathrm{C}, 50 \%$ rel. humidity, inspiratory flow $6 \mathrm{~L} / \mathrm{min}$ for babies* ${ }^{*} 12 \mathrm{~L} / \mathrm{min}$ for children** and $20 \mathrm{~L} /$ min for adults ${ }^{* *}$; compressor pressure 1,6 bar with LC SPRINTs, 1.2 bar with LC PLUS

due to high amount of particles produced, allow to reconcile good aerosol quality with a shorter inhalation time. In the case of Jet nebuliser systems, an important role is played by educating patients and their families, making them aware that a short inhalation time is important, but for the health of their child it is more important to obtain the appropriate concentration of the drug in the lungs.

When choosing the right inhalation device for a cystic fibrosis patient, the following should be considered:

- the form of the drug,

- characteristics of the nebuliser and the aerosol,

- the patient's age,

- the possibility for the patient to inhale synchronized with the device,

- the severity of your lung disease, including the occurrence of complications (e.g. haemoptysis, pneumothorax),

- device availability,

- patient's acceptance [7].

Mostly Jet and MESH nebuliser systems find application in cystic fibrosis. They vary in efficiency, aerosol quality and drug delivery to the lungs. In both cases, liquid solutions of the drug are used. The characteristics and techniques of using nebulisers are presented in Tables 2 and 3 .

\section{Selection of individual pressure and powder inhalers}

Most inhaled medications for people with cystic fibrosis are administered through nebulisers. However, due to the ease and convenience in everyday use of pMDI and DPI inhalers, it is recommended to use them instead of nebulisers whenever possible and in accordance with the manufacturer's instructions. The choice of pMDI or DPI should depend on the patient's age and ability to perform a specific respiratory maneuver (Table 4). pMDI should be used with an valved holding chamber (VHC), and for children under 3 years of age VHC with mask should be attached. Patients from the age of 5 can use DPI.

\section{Principles of inhalation medication administration}

It is very important to select the nebuliser and compressor correctly, in accordance with the recommendations of the attending physician and the manufacturer. Any inhalation medication should only be administered with an appropriate device. Most cystic fibrosis inhaled medications are licensed for use with pneumatic nebulisers. However, recently new antibiotics have been introduced for use with vibrating membrane nebulisers or DPI (Table 5). Their use 
Table 3. Advantages and disadvantages of different types of nebulisers [12]

\begin{tabular}{|c|c|c|}
\hline Type of nebuliser & Advantages & Disadvantages \\
\hline $\begin{array}{l}\text { Jet nebulisers with a corrugated } \\
\text { tubing (choice depending } \\
\text { on MMD/MMAD and FPF) }\end{array}$ & $\begin{array}{c}\text { Easy to use } \\
\text { Low drug waste } \\
\text { The nebuliser insert can be replaced depending } \\
\text { on the size of the drug particles* } \\
\text { Effective in delivering drugs, which cannot be } \\
\text { delivered by pMDI and DPI }\end{array}$ & Drug losses due to ineffective nebulisation \\
\hline $\begin{array}{l}\text { Breath-actuated and Breath- } \\
\text {-enhanced jet nebulisers }\end{array}$ & $\begin{array}{l}\text { Drug is delivered by inhalation only } \\
\text { Easy to use } \\
\text { Low drug waste } \\
\text { More efficient than a continuous nebulizer } \\
\text { Effective at delivering drugs that cannot be } \\
\text { delivered by pMDI and DPI }\end{array}$ & $\begin{array}{l}\text { Requires that sufficient inspiratory flow } \\
\text { is achieved to initiate drug delivery } \\
\text { The drug delivery takes longer }\end{array}$ \\
\hline Ultrasonic nebulisers & Easy to use & $\begin{array}{c}\text { More expensive than pneumatic nebulisers. } \\
\text { Large residual volume } \\
\text { Inability to spray viscous solutions } \\
\text { in the form of an aerosol } \\
\text { Damage to the structure of heat-sensitive drugs }\end{array}$ \\
\hline $\begin{array}{l}\text { Mesh (type MESH) } \\
\text { nebulisers }\end{array}$ & $\begin{array}{c}\text { Fast, quiet, portable. } \\
\text { It has an independent power source } \\
\text { Optimization of particles' sizefor specific drugs } \\
\text { More efficient than other nebulisers } \\
\text { Easy to use }\end{array}$ & $\begin{array}{c}\text { More expensive } \\
\text { Cleaning more difficult. } \\
\text { The dose of the drug should be adjusted } \\
\text { when changing } \\
\text { from the Jet nebuliser } \\
\text { Not compatible with viscous liquids } \\
\text { or those that crystallize during drying } \\
\text { (do not give salt with hyaluronic acid) }\end{array}$ \\
\hline
\end{tabular}

* applies to PARI nebulisers

**antibiotics are highly viscous formulation, nevertheless very efficient to be nebulised with eFlow rapid

Table 4. Selection of inhaler and interface depending on the patient's age based on [13]

\begin{tabular}{lcccc}
\hline Age & $\mathbf{0 - 3}$ years & $\mathbf{3 - 5}$ years & $\mathbf{6 - 1 2}$ years & $\geq \mathbf{1 3}$ years \\
\hline Inhaler type & $\begin{array}{c}\text { Nebuliser* } \\
\text { or pMDI with VHC }\end{array}$ & $\begin{array}{c}\text { Nebuliser, } \\
\text { pMDI with VHC }\end{array}$ & $\begin{array}{c}\text { Nebuliser, pMDI with VHC, DPI, breath activated } \\
\text { pMDI or breath-activated nebuliser }\end{array}$ & All types \\
Interface & Mask & $\begin{array}{c}\text { Mask or mouthpiece } \\
\text { with nose clip }\end{array}$ & Mouthpiece with nose clip & $\begin{array}{c}\text { Mouthpiece } \\
\text { with nose clip }\end{array}$ \\
\hline
\end{tabular}

*breath-activated nebulisers are not recommended

significantly shortens the inhalation time, with comparable effectiveness, and improves compliance with recommendations $[8,9]$. However, it should be remembered that new inhaled medications are registered with the device intended for their administration. By administering older drugs with the use of modern nebulisers, e.g. mesh instead of pneumatic, the pharmacokinetics of the drug changes. The dose may need to be adjusted to avoid side effects, especially for younger children. In some cases that is not necessary when switching from PARI jet nebs to eFlow rapid. A general overview of inhaled drugs and devices dedicated to their administration is presented in Table 6.

\section{Inhaled antibiotics}

Inhaled antibiotic therapy is the basic procedure for the eradication and treatment Pseudomonas aeruginosa chronic respiratory infections, which are the main cause of bronchopulmonary disease progression and death in patients with cystic fibrosis. Its use has an advantage over systemic therapy, as a relatively high concentration of the drug is delivered directly to the lungs, thus improving the pharmacokinetic and pharmacodynamic properties, while reducing the risk of toxicity. Correct administration of antibiotics such as colistin, tobramycin, aztreonam or levofloxacin is essential, both in terms of device selection and administration schedule (Table 7). The alternating 
Table 5. Devices for the inhalation of drugs in patients with cystic fibrosis [14]

\begin{tabular}{lccc}
\hline Drug & Nebuliser & DPI* & pMDI** \\
\hline Hipertonic saline & + & - & - \\
Mannitol & - & + & - \\
Dornase alfa & + & - & - \\
Bronchodilators & + & + & + \\
Inhaled corticosteroids & + & + & + \\
Tobramycin & + & + & - \\
Colistin & + & + & - \\
Aztreonam & + & - & - \\
Liposomal amphotericin & + & - & - \\
Liposomal amikacin & + & - & - \\
Ciprofloxacin & - & + & - \\
Vankomycin & - & + & - \\
Levofloxacin & + & - & - \\
\hline *DPl & & &
\end{tabular}

${ }^{*} \mathrm{DPI}$ — dry powder inhaler; ${ }^{* *} \mathrm{pMDI}$ — pressurized, metered-dose inhaler

cycles of antibiotics from different groups are increasingly recommended as a strategy to improve treatment outcomes, especially in patients with advanced lung disease [20]. In Poland, the limited access to inhaled antibiotics is a huge problem: only the preparation of colistin (Colistin TZF) is reimbursed, while tobramycin is available as part of a drug program, that excludes colistin interchangeability. The restrictive eligibility criteria for the drug program significantly limit the availability of highly concentrated tobramycin preparations for inhalation.

\section{Practical aspect of inhalation treatments}

To optimize the effectiveness of treatment, it is very important to follow the principles and procedures of physiotherapy, which include:

- compliance with the procedures for combining inhalation and drainage treatments,

- use of appropriate breathing and positioning techniques,

- use in inhalations of increased expiratory pressure (PEP - positive expiratory pressure),

- correct operation of the inhaler,

- continuous education of patients and their families.

- cleaning and disinfection of inhalers.

Procedures for combining inhalation

and drainage treatments

- Bronchodilators - usually 10-15 minutes before physiotherapy; it is recommended to use them before inhalation with hypertonic saline or an antibiotic to prevent bronchospasm.

- Hypertonic saline solutions - immediately before physiotherapy, but after administration of a bronchodilator. It can also be administered during airway clearance in combination with PEP or with oscillating positive expiratory pressure OPEP (OPEP). This saves the patient's time, but while it improves the deposition in the peripheral airways, the total lung deposition is reduced, so an increase in volume of the drug is often suggested, e.g. up to 5-6 mL. It should also be kept in mind that the drainage performed in this way is much less effective, and therefore it may be recommended for daily physiotherapy only in patients with a very bad motivation.

- Dornase alfa (rhDNase) - usually nebulisation is performed after drainage and after at least 1.5-2 hours another drainage is performed. In some cases, however, the drainage time may be set individually. Based on a Cochrane review, it was found that dornase alfa can be administered before or after bronchial drainage, individually, depending on the patient [15]. It can be administered exceptionally in the evening, before going to bed. This decision should be made by the attending physician. At night, the patient's parents or guardians should monitor for excessive coughing. It should be emphasized that administering rhDNase in the evening is an exceptional situation and should not be a routine practice.

- Inhaled glucocorticosteroids - usually used after physiotherapy.

- Inhaled antibiotics - both dry powder inhalers and nebuliser solutions should be used after physiotherapy. Appropriate nebuliser systems should be used for antibiotics, depending on the manufacturer's recommendations (Table 8).

It should be remembered that the patient should rinse the oral cavity after both the use of steroids and after inhalation of dornase alfa, hypertonic saline solution and an antibiotic.

\section{Breathing and positioning techniques}

The use of breathing techniques that increase the deposition of the drug in the lungs depends on the age, severity of the disease and the patient's motivation. They can be used in cooperating patients with a very good motivation. Patients who are weakly motivated or who cannot cooperate yet, such as preschool children, are better advised 
Table 6. Inhaled drugs used in patients with cystic fibrosis and nebulisers recommended by manufacturers

\begin{tabular}{|c|c|c|c|c|c|c|}
\hline Drug & Trade name & Dosage & Nebuliser & $\begin{array}{l}\text { Expiratory } \\
\text { filter }\end{array}$ & Time from ACT & Comments \\
\hline \multicolumn{7}{|l|}{ Inhaled antibiotics } \\
\hline $\begin{array}{l}\text { Liposomal } \\
\text { amikacin }\end{array}$ & Arikayce & $590 \mathrm{mg} / 8.4 \mathrm{~mL}$ OD & $\begin{array}{l}\text { Lamira Nebuliser } \\
\text { System }\end{array}$ & yes & after ACT & $\begin{array}{c}\text { alternating cycles } \\
\text { of } 28 \text { days }\end{array}$ \\
\hline $\begin{array}{l}\text { Aztreonam } \\
\text { lysine }\end{array}$ & Cayston & $75 \mathrm{mg}$ TID & $\begin{array}{l}\text { Altera nebuliser } \\
\text { with eFlow } \\
\text { controller unit }\end{array}$ & yes & after ACT & $\begin{array}{l}\text { alternating cycles } \\
\text { of } 28 \text { days }\end{array}$ \\
\hline $\begin{array}{l}\text { Colistimethate } \\
\text { sodium }\end{array}$ & Colistin TZF & $\begin{array}{l}\text { 1-2 mln IU BID/TID } \\
\max 6 \mathrm{mln} \text { IU/day }\end{array}$ & $\begin{array}{l}\text { PARI LC STAR, eFlow } \\
\text { rapid, PARI LC SPRINT, } \\
\text { PARI LC PLUS* }\end{array}$ & yes & after ACT & chronic therapy \\
\hline $\begin{array}{l}\text { Colistin nebuli- } \\
\text { ser solution }\end{array}$ & Promixin & $\begin{array}{l}\text { 1-2 mln IU BID/TID } \\
\max 6 \mathrm{mln} \text { IU/day }\end{array}$ & $\begin{array}{l}\text { PARI LC SPRINT, } \\
\text { I-neb AAD-System; } \\
\text { eFlow rapid }\end{array}$ & $\mathrm{n} / \mathrm{a}$ & after ACT & chronic therapy \\
\hline Lewofloxacin & Quinsair & 240 mg BID & $\begin{array}{l}\text { Zirela nebuliser } \\
\text { with eFlow } \\
\text { controller unit }\end{array}$ & yes & after ACT & $\begin{array}{l}\text { alternating cycles } \\
\text { of } 28 \text { days }\end{array}$ \\
\hline \multirow[t]{6}{*}{ Tobramycin } & Bramitob & 300 mg/4mL BID & $\begin{array}{l}\text { PARI LC PLUS } \\
\text { or PARI LC SPRINT/ } \\
\text { /PARI BOY Pro }\end{array}$ & yes & after ACT & $\begin{array}{l}\text { alternating cycles } \\
\text { of } 28 \text { days }\end{array}$ \\
\hline & Tobi & 300 mg/5 mL BID & PARI LC PLUS & yes & after ACT & $\begin{array}{c}\text { alternating cycles } \\
\text { of } 28 \text { days }\end{array}$ \\
\hline & Vantobra & $170 \mathrm{mg} / 1.7 \mathrm{~mL}$ BID & $\begin{array}{l}\text { Tolero nebuliser } \\
\text { with eflow } \\
\text { controller unit }\end{array}$ & yes & after ACT & $\begin{array}{l}\text { alternating cycles } \\
\text { of } 28 \text { days }\end{array}$ \\
\hline & $\begin{array}{l}\text { Tobramycin } \\
\text { Via Pharma }\end{array}$ & 300 mg/5 mL BID & $\begin{array}{c}\text { PARI LC PLUS, } \\
\text { PARI LC SPRINT STAR }\end{array}$ & yes & after ACT & $\begin{array}{c}\text { alternating cycles } \\
\text { of } 28 \text { days }\end{array}$ \\
\hline & $\begin{array}{c}\text { Tobramycyna } \\
\text { SUN }\end{array}$ & 300 mg/5 mL BID & $\begin{array}{c}\text { PARI LC PLUS, } \\
\text { PARI LC SPRINT STAR }\end{array}$ & yes & after ACT & $\begin{array}{l}\text { alternating cycles } \\
\text { of } 28 \text { days }\end{array}$ \\
\hline & Tobi Podhaler & $\begin{array}{c}112 \text { mg (4 kaps) } \\
\text { BID }\end{array}$ & podhaler DPI & $\mathrm{n} / \mathrm{a}^{* *}$ & after ACT & $\begin{array}{c}\text { alternating cycles } \\
\text { of } 28 \text { days }\end{array}$ \\
\hline \multicolumn{7}{|l|}{ Anti-fungal drugs } \\
\hline $\begin{array}{l}\text { Amphotericina B } \\
\text { liposomal }\end{array}$ & Ambisome & $50 \mathrm{mg} /$ week & $\begin{array}{l}\text { I-neb, PARI LC } \\
\text { SPRINT STAR }\end{array}$ & $n / a^{* *}$ & after ACT & \\
\hline \multicolumn{7}{|l|}{ Mucolytics } \\
\hline Dornase alfa & Pulmozyme & $2.5 \mathrm{mg} \mathrm{OD}$ & $\begin{array}{l}\text { Pari LC PLUS, } \\
\text { eFlow rapid }\end{array}$ & no & $\begin{array}{l}\text { usually after } \\
\text { ACT and not } \\
\text { earlier than } \\
>1.5-2 \text { hours } \\
\text { before the next } \\
\text { ACT }\end{array}$ & \\
\hline $\begin{array}{l}\text { Hypertonic } \\
\text { saline }\end{array}$ & & $3-7 \%$ & $\begin{array}{l}\text { Nebuliser Jet, } \\
\text { eFlow rapid, I-neb }\end{array}$ & no & $\begin{array}{l}\text { immediately } \\
\text { before or during } \\
\text { the ACT }\end{array}$ & \\
\hline Mannitol*** & Bronchitol & $\begin{array}{c}400 \mathrm{mg} \text { (10 kaps) } \\
\text { BID }\end{array}$ & DPI & no & after ACT & $\begin{array}{l}\text { High risk of } \\
\text { bronchospasm }\end{array}$ \\
\hline
\end{tabular}

ACT — airway clearance technique (based on [8-11, 16-19]); QD — once a day; BID — twice a day; TID — three times a day

${ }^{*}$ no manufacturer indications regarding the type of nebulisers, the recommendations are based on the experience of Polish experts

** n/a (not applicable)

*** third line drug in patients not responding to treatment with dornase alfa and hypertonic saline 
Table 7. Antibiotics used in nebulisation solution in Pseudomonas aeruginosa respiratory tract infection in patients with cystic fibrosis - based on [20]

\begin{tabular}{|c|c|c|c|c|c|c|}
\hline Antibiotics & Antibiotic group & Mechanism of action & Trade name & $\begin{array}{c}\text { Nebulisation } \\
\text { time }\end{array}$ & Dose & Frequency \\
\hline \multirow[t]{6}{*}{ Tobramycin } & \multirow[t]{6}{*}{ Aminoglycosides } & \multirow[t]{6}{*}{ Inhibition of protein synthesis } & Tobramycin & $15 \min$ & $300 \mathrm{mg} / 5 \mathrm{~mL}$ & BID \\
\hline & & & Tobi & $15 \min$ & $300 \mathrm{mg} / 5 \mathrm{~mL}$ & BID \\
\hline & & & Bramitob & $15 \min$ & $300 \mathrm{mg} / 4 \mathrm{~mL}$ & BID \\
\hline & & & Vantobra & $4 \min$ & $170 \mathrm{mg} / 1.7 \mathrm{~mL}$ & $\mathrm{BID}$ \\
\hline & & & $\begin{array}{l}\text { Tobramycin } \\
\text { Via Pharma }\end{array}$ & $15 \mathrm{~min}$ & $300 \mathrm{mg} / 5 \mathrm{~mL}$ & $\mathrm{BID}$ \\
\hline & & & $\begin{array}{l}\text { Tobramycyna } \\
\text { SUN }\end{array}$ & $15 \mathrm{~min}$ & $300 \mathrm{mg} / 5 \mathrm{~mL}$ & BID \\
\hline $\begin{array}{l}\text { Aztreonam } \\
\text { lysine }\end{array}$ & Monobactams & $\begin{array}{l}\text { Inhibition of bacterial wall } \\
\text { protein synthesis }\end{array}$ & Cayston & $2-3 \min$ & $75 \mathrm{mg} / 1 \mathrm{~mL}$ & TID \\
\hline Levofloxacin & Fluoroquinolones & $\begin{array}{l}\text { Effect on DNA gyrase } \\
\text { and topoisomerase IV }\end{array}$ & Quinsair & $5 \mathrm{~min}$ & $240 \mathrm{mg} / 2.4 \mathrm{~mL}$ & BID \\
\hline \multirow{2}{*}{$\begin{array}{l}\text { Sodium } \\
\text { colistimethate }\end{array}$} & \multirow[t]{2}{*}{ Polimyxin } & \multirow{2}{*}{$\begin{array}{l}\text { Disturbance in the structure } \\
\text { of bacterial cell membrane }\end{array}$} & Promixin & $3 \mathrm{~min}$ & $80 \mathrm{mg} / 3 \mathrm{~mL}$ & $\mathrm{BID} / \mathrm{TID}$ \\
\hline & & & Colistin TZF & $15-30 \mathrm{~min}$ & $1 \mathrm{mln}$ IU $(80 \mathrm{mg})^{*}$ & $\mathrm{BID} / \mathrm{TID}$ \\
\hline
\end{tabular}

BID — twice a day; TID — three times a day

* 1 vial contains 1 million IU (80 mg) of lyophilisate for solution for injection, infusion and inhalation

Table 8. Recommendations for cleaning and disinfection of nebulisers used by patients with cystic fibrosis at home and during hospital stay [21]

Recommendations for the hygiene of nebulisers

At home In the hospital

1. Wash your hands thoroughly with soap and water and use a hand disinfectant gel before cleaning the nebuliser

Medical personnel should wear gloves and, after taking them off, follow recommendation 1

2. Disconnect the nebuliser from the compressor or controller and disassemble it

3. Washing: wash the nebuliser parts in a solution of warm water and dishwashing liquid according to the manufacturer's recommendations

4. Location: do not wash the nebuliser parts directly in the kitchen or bathroom sink or in the dishwasher. The nebuliser parts should be washed in a dedicated plastic, glass or metal bowl in the patient's kitchen

5. Rinsing: use distilled water for the final rinse, if any disinfection is not possible

6. Wastewater treatment: dirty water should be poured down the toilet, its lid should be closed before flushing

4. Location: nebuliser parts should be washed in a disposable bowl, metal bowl or wash basin (but not directly in the sink) in the patient room

7. Wash your hands thoroughly with soap and water and use hand disinfectant gel

8. Disinfection:

the washed and rinsed nebulisers should then be disinfected after each use in an electric steam steriliser or scaled

$$
\text { in boiling water }
$$

6. Disposal of sewage: the metal bowl with dirty water should be taken to the departmental lock and poured out there, the metal bowl should be sterilized in an autoclave

\section{Disinfection:}

washed and rinsed nebulisers should be disinfected immediately after each use in an electric steam steriliser or reusable nebulisers can be autoclaved as recommended by the manufacturer

9. Drying: nebulisers should be thoroughly dried

10. Storage: leave the disinfected nebuliser parts in a closed box until next use (within 24 hours) 
to breathe calmly, in a natural breathing rhythm appropriate for each patient. A sitting position should be used during inhalation. However, in some patients, drug deposition may improve positioning in positions other than sitting. By using gravity, a better effect of sedimentation and deposition of drug particles in areas with a significant degree of disturbance of ventilation can be obtained. The physiotherapist decides whether to use certain positions.

\section{Use of elevated expiratory pressure (PEP) during inhalation}

Some devices operating in the PEP system can be connected to Jet nebulisers. However, there are no clear recommendations regarding the use of PEP for inhalation. Study results concerning differences of aerosol deposition in the lungs when inhaled with or without PEP are inconclusive. Studies show that when PEP is used, significantly less aerosol is deposited in the lungs than when inhaled without PEP [23]. At the same time, better aerosol deposition and more proportional aerosol distribution in the peripheral bronchi during inhalation with PEP than without PEP was observed [23, 24]. The condition for the use of PEP is good cooperation with the patient and knowledge of breathing techniques that reduce drug losses during exhalation with resistance.

\section{Correct use of the inhalation device}

Proper handling of the inhalation device allows for its trouble-free operation for many years and the production of good-quality aerosols. Attention should be paid to the correct cleaning of the jet-nebuliser or the perforated membrane in the MESH nebuliser system, replacement of the air filter in the compressor and the systematic replacement of used nebulisers and compressors with new ones.

\section{Continuous education of patients and their families}

The effectiveness of inhalation therapy depends on the inhalation technique and adherence to recommendations. Patients and their parents / guardians should receive repeated training in physiotherapy. In case of lack of the expected results of treatment, the method of performing inhalation and drainage procedures should always be checked and re-education should be performed.

\section{Cleaning and disinfection of nebulisers}

Proper daily use of inhalation devices is aimed at ensuring optimal drug delivery and the prevention and control of infections [21, 22, 25]. Currently, there is a great need for education in this area, especially adults. The following are guidelines for cleaning and disinfecting nebulisers in both home and hospital settings (Table 8).

1. Always wash and disinfect new parts of the nebuliser before first use.

2. During a hospital stay as well as at home, wash and steam the parts of the nebuliser after each use.

3. The nebuliser should be washed and disinfected again immediately before use if it has not been used for more than 24 hours.

4. After boiling or steaming in a steam disinfector, the parts of the nebuliser should be immediately removed from the water or the steamer, and dried quickly and thoroughly. A sterilizer with a drying function can be used. Do not leave the nebuliser parts to dry on the dryer or on the edge of the wash basin or sink.

5. After cleaning the nebuliser, hands should be washed thoroughly with soap and water and hand disinfectant gel should be used.

This consensus was developed by a group of Polish experts experienced in the treatment of cystic fibrosis.

This publication was prepared without any external sources of funding.

\section{Conflicts of interest}

None declared.

\section{References:}

1. Bell SC, Mall MA, Gutierrez H, et al. The future of cystic fibrosis care: a global perspective. Lancet Respir Med. 2020; 8(1): 65-124, doi: 10.1016/S2213-2600(19)30337-6, indexed in Pubmed: $\underline{31570318 .}$.

2. Castellani C, Duff AJA, Bell SC, et al. ECFS best practice guidelines: the 2018 revision. J Cyst Fibros. 2018; 17(2): 153-178, doi: 10.1016/j.jcf.2018.02.006, indexed in Pubmed: 29506920.

3. Bradley J. Standards of Care and Good Clinical Practice for the Physiotherapy Management of Cystic Fibrosis: CF Trust Physiotherapy Guidelines 2011. Cystic Fibrosis Trust : 2011.

4. Flume PA, Robinson KA, O’Sullivan BP, et al. Clinical Practice Guidelines for Pulmonary Therapies Committee. Cystic fibrosis pulmonary guidelines: airway clearance therapies. Respir Care. 2009; 54(4): 522-537, indexed in Pubmed: 19327189.

5. Kaur R, Kaur R, Singh C, et al. Inhalational drug delivery in pulmonary aspergillosis. Crit Rev Ther Drug Carrier Syst. 2019; 36(3): 183-217, doi: 10.1615/CritRevTherDrugCarrierSyst.2018025781, indexed in Pubmed: 31679246.

6. Bos AC, van Holsbeke C, de Backer JW, et al. Patient-specific modeling of regional antibiotic concentration levels in airways of patients with cystic fibrosis: are we dosing high enough? PLoS One. 2015; 10(3): e0118454, doi: 10.1371/journal.pone.0118454, indexed in Pubmed: 25734630.

7. Daniels T, Mills N, Whitaker P, et al. Nebuliser systems for drug delivery in cystic fibrosis. Paediatr Respir Rev. 2013; 14(2): 
98-99, doi: 10.1016/j.prrv.2013.03.004, indexed in Pubmed: 23583049 .

8. Hubert D, Leroy S, Nove-Josserand R, et al. Pharmacokinetics and safety of tobramycin administered by the PARI eFlow rapid nebulizer in cystic fibrosis. J Cyst Fibros. 2009; 8(5): 332-337, doi: 10.1016/j.jcf.2009.07.001, indexed in Pubmed: 19651542.

9. Lenney W, Edenborough F, Kho P, et al. Lung deposition of inhaled tobramycin with eFlow rapid/LC Plus jet nebuliser in healthy and cystic fibrosis subjects. J Cyst Fibros. 2011; 10(1): 9-14, doi: 10.1016/j.jcf.2010.08.019, indexed in Pubmed: 20884302.

10. Govoni M, Poli G, Acerbi D, et al. Pharmacokinetic and tolerability profiles of tobramycin nebuliser solution $300 \mathrm{mg} / 4 \mathrm{ml}$ administered by PARI eFlow(®) rapid and PARI LC Plus(® nebulisers in cystic fibrosis patients. Pulm Pharmacol Ther. 2013; 26(2): 249-255, doi: 10.1016/i.pupt.2012.12.002, indexed in Pubmed: 23232039.

11. Schwarz C, Schulte-Hubbert B, Bend J, et al. CF Lung Disease a German S3 Guideline: Module 2: Diagnostics and Treatment in Chronic Infection with Pseudomonas aeruginosa]. Pneumology. 2018; 72(5): 347-92.

12. Ari A. Jet, Ultrasonic, and Mesh Nebulizers: An evaluation of nebulizers for better clinical outcomes. Eurasian Journal of Pulmonology. 2014; 16(1): 1-7, doi: 10.5152/ejp.2014.00087.

13. Ari A, Fink JB. Guidelines for aerosol devices in infants, children and adults: which to choose, why and how to achieve effective aerosol therapy. Expert Rev Respir Med. 2011; 5(4): 561-572, doi: 10.1586/ers.11.49, indexed in Pubmed: $\underline{21859275}$.

14. Tiddens HA, Bos AC, Mouton JW, et al. Inhaled antibiotics: dry or wet? Eur Respir J. 2014; 44(5): 1308-1318, doi: 10.1183/09031936.00090314, indexed in Pubmed: 25323242.

15. Yang C, Montgomery M, Yang C, et al. Dornase alfa for cystic fibrosis. Cochrane Database Syst Rev. 2016; 4: CD001127-67, doi: 10.1002/14651858.CD001127.pub3, indexed in Pubmed: 27043279 .

16. Kirkby S, Novak K, McCoy K. Aztreonam (for inhalation solution) for the treatment of chronic lung infections in patients with cystic fibrosis: an evidence-based review. Core Evid.
2011; 6: 59-66, doi: 10.2147/CE.S11181, indexed in Pubmed: 22022288

17. Bilton D, Fajac I, Pressler T, et al. CLEAR-110 Study Group, CLEAR-108 Study Group. Amikacin liposome inhalation suspension for chronic Pseudomonas aeruginosa infection in cystic fibrosis. J Cyst Fibros. 2020; 19(2): 284-291, doi: 10.1016/j. icf.2019.08.001, indexed in Pubmed: 31451351.

18. Elborn JS, Flume PA, Cohen F, et al. Safety and efficacy of prolonged levofloxacin inhalation solution (APT-1026) treatment for cystic fibrosis and chronic Pseudomonas aeruginosa airway infection. J Cyst Fibros. 2016; 15(5): 634-640, doi: 10.1016/i. icf.2016.01.005, indexed in Pubmed: 26935334.

19. Wark P, McDonald VM, Wark P, et al. Nebulised hypertonic saline for cystic fibrosis. Cochrane Database Syst Rev. 2009; 9(2): CD001506, doi: 10.1002/14651858.CD001506.pub3, indexed in Pubmed: 19370568.

20. Taccetti G, Francalanci M, Pizzamiglio G, et al. Cystic Fibrosis: Recent insights into inhaled antibiotic treatment and future perspectives. Antibiotics (Basel). 2021; 10(3), doi: 10.3390/ antibiotics10030338, indexed in Pubmed: 33810116.

21. Bell J, Alexander L, Carson J, et al. Nebuliser hygiene in cystic fibrosis: evidence-based recommendations. Breathe (Sheff). 2020; 16(2): 190328, doi: 10.1183/20734735.0328-2019, indexed in Pubmed: 32684992.

22. MacFarlane M, Carson L, Crossan A, et al. Nebuliser cleaning and disinfection practice in the home among patients with cystic fibrosis. J Infect Prev. 2020; 21(1): 14-22, doi: 10.1177/1757177419855603, indexed in Pubmed: 32030099.

23. Laube BL, Geller DE, Lin TC, et al. Positive expiratory pressure changes aerosol distribution in patients with cystic fibrosis. Respir Care. 2005; 50(11): 1438-1444, indexed in Pubmed: 16253150.

24. Orlik T, Sands D. The use of increased expiratory pressure (PEP) in inhalations in patients with cystic fibrosis. Med Age of Roz. 2015; XIX(1): 50-59.

25. Heijerman H, Westerman E, Conway S, et al. consensus working group. Inhaled medication and inhalation devices for lung disease in patients with cystic fibrosis: A European consensus. J Cyst Fibros. 2009; 8(5): 295-315, doi: 10.1016/j. jcf.2009.04.005, indexed in Pubmed: 19559658. 